\title{
EFFICIENCYMEASUREMENT OF ZAKAT INSTITUTION PROGRAM: CASE STUDY DOMPET DHUAFA INDONESIA
}

\author{
Aam Slamet Rusydiana ${ }^{1}$ Hasna Maliha $^{2}$, Salman Al-Parisi ${ }^{3}$
}

\section{* Affiliation:}

${ }^{1}$ Researcher at Sharia Economic Applied Research \& Training (SMART) Consulting, Indonesia. Email: aamsmart@gmail.com This paper is under the desk IZZat (Institute of Zakat and Zero Riba Studies).

${ }^{2}$ Researcher at SMART Consulting.

${ }^{3}$ Junior researcher at SMART Consulting.

\begin{abstract}
Although social based, Zakat Institutions (OPZ) need to uphold professionalism, transparency and accountabilityin its management. Most recently, Zakat Core Principles is known as the measurement of zakat fundmanagement. This study would try to measure the efficiency of DompetDhuafa's program as Decision Making Unit (DMU) in the level of efficiencyusing Data Envelopment Analysis (DEA) method. And also the research would look at the possibility of potential improvement from inefficient DompetDhuafa's programs, input-output contribution and the reference contribution of the DMU. The results show that there are 6 DMU that efficient $(100 \%)$ and inefficient as much as 18 DMU. The most inefficient program is wakaf fund (2012). In general, the main factor inefficiency of DompetDhuafa program from 2010 to 2013 due to the distribution fund of DompetDhuafa program such as zakat, wakaf, humanity etc to ashnaf which is still less optimal.The distribution fund also has to increase up to $75.38 \%$, then it is able to resolve the problem of poverty.
\end{abstract}

Keywords: Zakat Institution Program, Efficiency, Data Envelopment Analysis

\section{INTRODUCTION}

Zakat is a stimulus in the economy which raises new force in the accumulation of a significant investment that would boost the production of the economy cycle in the region. From the macro side, zakat would be able to increase an aggregate demand due to increase purchasing power of community for goods and services. When zakat implemented by good governance system, then it would be trigger to the emergence of job opportunity, in order every citizen has a job and it is able to reduce poverty automatically. Furthermore, zakat has a main role in the creation of justice in the economic field, in which all citizens have a source of revenue and income to fulfill daily needs for their life.

There are many zakat institution in Indonesia such as BAZNAS, Rumah Zakat Indonesia (RZI), PKPU, DompetDhuafa, YDSF and so on. 
Every zakat institution has some programsboth in collection and distribution of zakat fund such as zakat fund, waqf, humanity and so on. If the programrun well in its management, then ashnaf will be good anyway. In other words, the most important thing of zakat institution is how to manage the programs (management of zakat collection and distribution).

Zakat Institution (OPZ) is the intermediary organizations based on social. The entire of operating expense is taken from the zakat and infaq funds. It is also justified by Sharia, because OPZ committee is Amilin zakat that also included in eight ashnaf eligible for zakat. (Akbar: 2009).

Although OPZ based on social, Zakat Institutions (OPZ) need to uphold professionalism, transparency and accountabilityin its management. Include in this term, OPZ need to operate effectively and efficiently. Most recently, in the measurement of zakat management, Baznasand IndonesianBank initiate concept of Zakat Core Principles (Beik et al, 2014).

In measuring the degree of efficiency, Data Envelopment Analysis (DEA) is preferable. According to research of Kamarudin et al (2008), Ozdemir (2013), Shahrekiet al (2012), TsolasandDimitris (2012), DEA is widely used to measure the level of technical efficiency, economic scale, industrial banks and financial institutions. But in this time, DEA is also used in measuring the efficiency of non-bank institutions, such as hospital, university, tax office, and including nonprofit institutions (Rusydiana: 2013).

The research related to efficiency of zakat institution has been done by several researchersactually. For example by Wahab and Rahman (2012), (2013), Noor et al (2015) and (2012) and Ahmad and Masturah (2014).But all of research in Malaysia.Only Akbar (2009), who makes Indonesia'sOPZ as an object of research.

In this case study would try to measure DompetDhuafa's programas Decision Making Unit (DMU) in the level of efficiency. And also the research would look at the possibility of potential improvement from inefficient DompetDhuafa's programs, input-output contribution and the reference contribution of the DMU. Therefore, based on the background described above, the formulation of problem in this study would try to answer the questions as follows:

1. Which DompetDhuafa's program has been efficient and not efficient?

2. How about total potential improvement of DompetDhuafa's program?

3. What is the the main inefficiency factor of DompetDhuafa program from 2010 to 2013 ?

4. How about the analysis of Return to Scale (RTS), Reference Frequencies and Input-Output Contribution of DompetDhuafa's program?

\section{THEORY}

The concept of efficiency come from the microeconomic concept, namely,consumer theory and producer theory. Consumer theory tried to maximize utility or satisfaction from individual views, while producer theory tried to maximize profit or minimize costsfrom producer views.

In the producer theory, there is a production frontier line that describes the relationship between inputs and outputs of production process. Thisproduction frontier line represents the maximum output from the use of each input. It also represents the technology that used by a business unit (DMU) or industry (market). The figure below shows the production frontier line. 


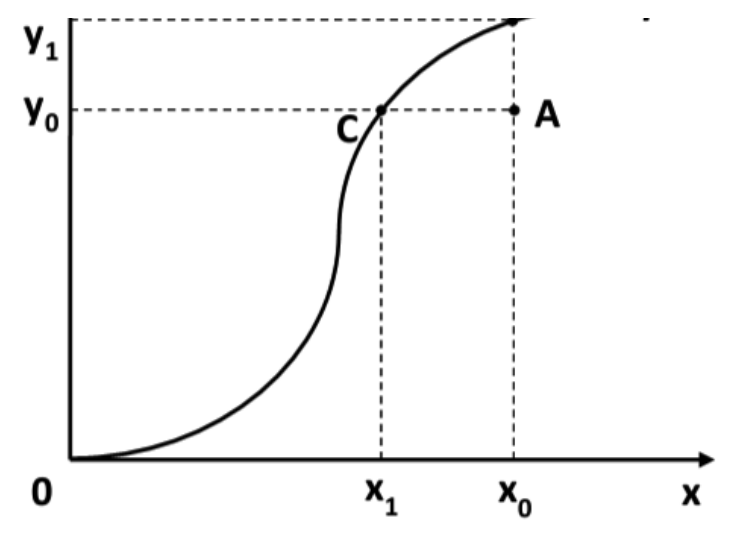

Figure 1. Production Frontier

Production process with singleinput $(\mathrm{x})$ to produce single output (y).Production frontier F' represents the maximum output attainable from each level. Point $\mathrm{B}$ and $\mathrm{C}$ represent efficient points with productivity $\left(\mathrm{y}_{1} / \mathrm{x}_{0}\right)$ and $\left(\mathrm{y}_{0} / \mathrm{x}_{1}\right)$, respectively. Point $A$ represent an inefficient point with productivity $\left(\mathrm{y}_{0} / \mathrm{x}_{0}\right)$, since technically it could increase output to $\mathrm{y}_{1}$ (the level associated with point $\mathrm{B}$ ) without requiring more input; or it could decrease input to $\mathrm{x}_{1}$ (the level associated with point $\mathrm{C}$ ) to produce similar $\mathrm{Y}_{0}$.

Efficiency comprises of two components, namely: a) Technical efficiency describes the ability of a business unit to maximize output givencertain amount of input; and b) Allocative efficiency describes the ability of a business unit to utilize inputs in optimal proportion based on their price. When two types ofefficiency combined, it will produce economic efficiency. A company is considered to be efficient economically if it can minimize the production costs to produce certain outputwithin common technology level and market price level (Farrel:1957).

Kumbhaker and Lovell (2000) argue that technical efficiency is only one of many components economic efficiency as a whole. Nevertheless, in order to achieve economicefficiency, a company should produce maximum output with certain amount of input (technical efficiency) and produce output with the right combination within certain pricelevel (allocative efficiency).

\section{THE MEASUREMENT OF EFFICIENCY}

In the past few years, performance measurement of financial institution has focused on frontier efficiency or X-efficiency (rather than scale efficiency), which measures deviation in performance of a decision making unit from the best practices orcosts-efficient frontier that depicts the lowest production costs for a given level of output. X-efficiency stems from technical efficiency, which gauges the degree of friction and waste in the production process, and allocative efficiency, which measures the levels ofvarious inputs.

Frontier efficiency is superior for most regulatory and other purposes to the standard financial ratios from accounting statements, such as, return on asset (ROA) orcost/revenue ratio, that are commonly employed by regulators, managers of financial institutions, or industrial consultants to assess financial performance. Frontier efficiency measures programming or statistical techniques that removes theeffects of differences in input prices and other exogenous 
market factors that affect the standard performance ratios in order to obtain better estimates of the underlyingperformance of the managers (Baueret al: 1998).

Efficiency measurement could be parametric and non-parametric. There are three parametric econometric approaches.: 1) Stochastic frontier approach (SFA); 2) Thick frontier approach (TFA); and 3)Distribution-free approach (DFA).

Meanwhile, non-parametric linear programming approach to measure efficiency uses non-stochastic approach and tends to combine disturbance into inefficiency. This is builtbased on discovery and observation from the population and evaluates efficiency relative to other units observed. One of the non-parametric approaches, known as data envelopment analysis (DEA).

DEA is a mathematical programming technique that measures therelative efficiency of a decision making unit (DMU) to other similar DMUs with the simple restrictions that all DMUs lie on or below the efficiency frontier (Cooper et al, 2002). The performance of a DMU is very relative to other DMUs, especially those that cause inefficiency. This approach can also determine how DMU can improve itsperformance to be efficient.

DEA was first introduced by Charnes, Cooper, and Rhodes in 1978. Its utilization and development has grown rapidly. The main advantage of DEA isunlike regression analysis, it does not require an a priori assumption about the analytical form of the production function soimposes very little structure on the shape of the efficient frontier. Instead, it constructs the best practice production function solely on the basis of observed data, and therefore thepossibility of misspecification of the production technology is zero.

On the other hand, the main disadvantage of DEA is that the frontier is sensitive to extreme observations andmeasurement error (the basic assumption is that random errors do not exist and that all deviations from the frontier indicate inefficiency).

\section{PREVIOUS STUDIES}

The study is about efficiency measurement of zakat institution done by Rusydiana et al (2016). Rusydiana et altry to measure the efficiency of 3 (three) Zakat Institutions (Baznas, PKPU and Rumah Zakat) with Data Envelopment Analysis (DEA) method. The results show that there are 12 fully efficient DMU (100\% efficient). Only 6 DMU inefficient. The main factor inefficiency Zakat Institution from 2007 to 2014 due to the distribution of zakat funds to ashnaf. It is still less optimal.

According to Akbar (2009), aims to determine the level of efficiency of Zakat Institutions in Indonesia using DEA with the production approach.This method measures the ratio between output and input, which are comparedbetween OPZ. Output variables used are collection of zakat fund and distribution of zakat fund, while input variables are personnel costs,socialization costs and other operational costs. The results show that the efficiency of OPZ in the year 2005 is still better than in 2006 and 2007, both technical (94.52\%), scale (75\%), and overall (71.27\%). Calculation of 9 OPZs in 2007 with the assumption of CRS, shows only $2 \mathrm{OPZ}$ is efficient, ie,BMM and Bamuis BNI. The main cause of inefficiency is distribution fund and collectionfund, which contributed $43.1 \%$ and $36 \%$. While the inputoriented states that the source of inefficiency isthe other operational costs $(34.9 \%)$ and the cost of socialization $(31.1 \%)$. 
Norazlina and Abdul (2012), to analyze the efficiency of zakat institutions in Malaysia by using data envelopmentanalysis (DEA) method to estimate zakat efficiency and Tobit model to determine the efficiency of zakat institution in Malaysia. Technicalefficiency, pure technical efficiency and scale efficiency of DEA modelbeing used.The empirical findings suggest that zakat payment, computerized zakat system, board size, audit committee and decentralization significantly affect the efficiency of zakat institutions in Malaysia.The analysis showed that fully corporatized zakat institutionsare positively associated with efficiency of zakat institutions in Malaysia while partially corporatized negatively affect on zakat efficiency.

Norazlina and Abdul (2011), in their framework to analyse the efficiency and governance of zakat institutions by using the DEA. They argued that the characteristics ofDEA are suitable for application to zakat institutions, as it was applied successfully as indicator for efficiency of non-profit and public sectors. Furthermore, Norazlina and Abdul (2012) measure theproductivity growth of zakat institutions by using the variable returns to scale (VRS) and they found that most of zakat institutions were operating at non-CRS (Constant Return Scale) . Thus, zakat institution need to improve the overall of efficiency.However, in their work, their study of efficiency seemed to focus on technical efficiency and scale efficiency.

Nur and Selamah (2013) analyze the profile of zakat collection institutions and the efficiency of the institutions in collecting the zakatby using Data Envelopment Analysis (DEA) approach. The study conducted in three states of Federal Territories including Kuala Lumpur, Putrajaya and Labuan. The results of the efficiency found thatall of the three areas of zakat institutions are efficient. The overall finding indicate that the center managed by Federal Territories maintaintheir performance and it is able to increase the total of zakat collections and number of new and existing zakat payers.

A zakat institution isa non-profit organization in its functionality. Berber et al (2011) suggested that two stage DEA analysis inmeasuring the efficiency of non-profit organization. The stage one measures the efficiency of fund-raising and the stage two measures thedelivery of service (in our case the distribution of zakat to the beneficiaries). The output of stage one is included in the input of stage two. Berber et al (2011) found that the separation of the fundraisingfunction from product delivery function will show a clearer analysis ofefficiency, as both efforts of fund raising and service delivery or distribution are equally important.

\section{CONCEPTUAL FRAMEWORK}

The first stage of this study is to determine the Decision Making Unit (DMU). DMU is an operational unit that will serve as a decision-making unit that will be tested the efficiency levels. The second stage is to determine the approach that would affect the determination of the input and output variables to be used for testing efficiency. And then, in the third stage is to choose the input and output variables.

In this study, the input and output variables derived from the financial statements of DompetDhuafa. The input consists of Operating Expenses (X1), and Socialization Cost (X2) while the output variables comprises of Total Deposits Zakat (Y1) and Total Fund Distribution (Y2). The fourth stage is to find and collect the data presented in tabular form in Microsoft Exel. The next stage is to select the model of DEA. In this study used a model CRS-VRS. This model 
is used to improve the company's internal activities which will result in technical efficiency, pure technical efficiency and scale efficiency. The last stage is the synthesis and analysis. The data has been compiled in tabular form in Microsoft Exel then imported into Banxiasoftware. Then the software by itself will perform the data processing of each input and output variables for each DMU. Synthesis results exported to Microsoft Exel returned for analysis.

Source: Tanjung and Devi (2013)

\section{METHODOLOGY}

This study applies Data Envelopment Analysis (DEA) method. DEA is a non-parametric method to measure the relative efficiency of production frontier based on the multiple inputs and outputs of decision making unit, in this case, zakat institution program (OPZ). The nonparametric nature of DEA does not require assumption of the production function and the DEA approach will generate the production function based on observed data, so the misspesification can be minimized.

DEA can be applied to analyze different kind of inputs and outputs without assigning weight. Morever, the efficiency produced is a relative efficiency based on observed data. The preference of the decision maker can also be accommodated in the model.

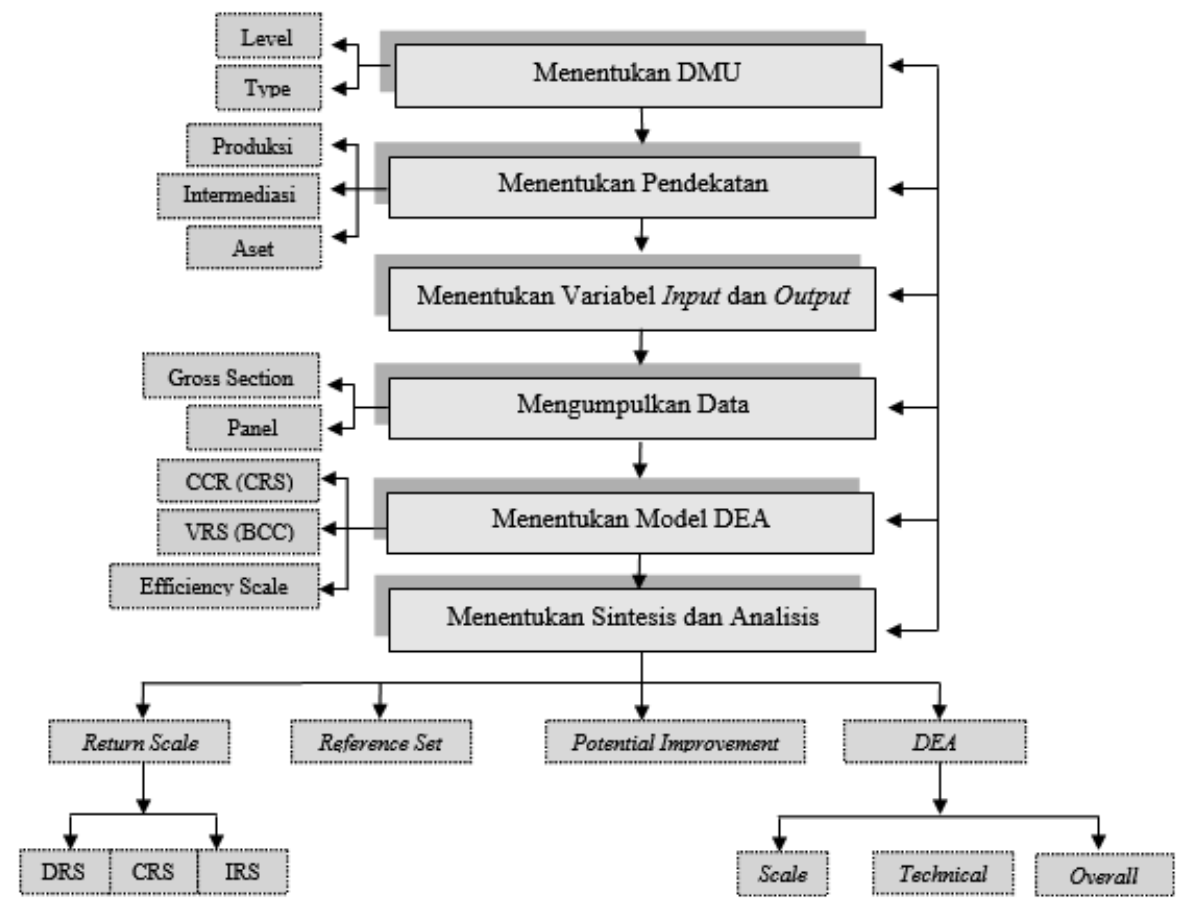

Figure 2. Stage of DEA Research

\section{Data Envelopment Analysis}

Data Envelopment Analysis is a methodology for analyzing the relative efficiency and managerial performance of decision making unit (DMU). The DEA allows us to compare the relative efficiency of DMU by firstly determine the efficient DMU as benchmarks and then measure the inefficiencies in input combinations (slack variables) of other DMU relative to the benchmark. Based on Charnes et al (1978) at the beginning, the application of DEA method widely used in the banking industry. 
The DEA is an alternative approach to regression analysis. While the regression analysis relies on central tendencies, DEA is based on external observations. Furthermore the regression approach applies a single estimated regression equation to each observation vector, while the DEA use and analyze each vector (DMU) separately to produce individual relative efficiency to the entire set under evaluation (Jemric and Vujcic: 2002).

From the set of available data, DEA identifies the reference points as relatively efficient DMUs then define the efficient frontier as the best practice production technology and finally evaluate the inefficiencies of other interior points. All the inefficient DMUs will lies below the efficient frontier. Besides producing efficiency value for each DMU, DEA also determines DMUs that are used as benchmark for other inefficient DMU.

$$
\text { Efficiencyof DMU }=\frac{\sum_{k=1}^{p} \mu_{k} y_{k 0}}{\sum_{i=1}^{m} v_{i} x_{i 0}}
$$

$\mathrm{DMU}=$ decision making unit

$\mathrm{m}=$ different inputs

$\mathrm{p}=$ different outputs

$\mathrm{uk}=$ the weight given to output $\mathrm{k}$ $\mathrm{n}=$ number of DMU evaluated

$\mathrm{xij}=$ number of input $\mathrm{i}$ consumed by DMUj

$\mathrm{ykj}=$ number of output $\mathrm{k}$ produced by $\mathrm{DMUj}$

$\mathrm{vi}=$ the weight given to input $\mathrm{i}$

DEA Model consists of twomodel, BCC and CCR. BCC model developed by Banker, et al (1984), while CCR model developed by Charnes, et al (1978). Both differ in their treatment on the return to scale (RTS). The BCC assumes each DMU can operate with variable return to scale (VRS), while the CCR model assumes each DMU operates with constant return to scale (CRS).

The choice of model, constant (CCR) or variable (BCC), depends on the process being analysed. The question to be asked is, if resources are increased by amount ' $x$ ', do outputs increase by the full amount ' $x$ ', or is there a proportionately higher or lower increase in outputs? If the answer is that any increase in input (resources) used yields a proportionate increase in outputs (results) then this indicates that a linear relationship between the inputs and outputs, so a constant returns to scale (CRS) model should be used. If however, an increase in inputs does not yield the same increase in outputs, then the variable returns to scale model should be used, as a non-linear relationship between results and resources has been identified (BCC) (Hussain and Jones: 2010).

Generally, the efficiency rating of CCR model for each DMU will not exceed the BCC model. This is due to BCC model analyze each DMU "locally", compared to the subset of DMUs that operate in the same region of return to scale, rather than "globally" (Jemric and Vujcic, 2002). The BCC model represents technical efficiency only, while the CCR model represents the multiplication of pure technical and scale efficiencies.

The Study in this research focused on measuring the efficiency level of DompetDhuafa program. The reason for selection of OPZ, because it publishs its annual financial statements relative consistently and comprehensively. The variable input consists of Operating Expenses (X1), and Socialization Cost (X2) while the output variables comprises of Total Deposits Zakat 
(Y1) and Total Fund Distribution (Y2). DEA score will be derived from these variables, which is the result of dividing the output and input factors (Charnes, et al: 1978).

This study uses secondary data from2010-2013 that was published as basic data, such as financial reports, balance sheet and cash flow statement. Data can be obtained from the publications issued by DompetDhuafa. However, due to limited data available, data is only 4 years from 2010-2013 (DD: 2016).

Furthermore, the study would attempt to answer some of questions focus on research. Among, how about the position of efficiency levels from each Zakat institution program from year to year and how about the scores distribution. How about Return to Scale (RTS) of each DMU and the potential improvement of DD program is not efficient yet. And also, this research would answer any inputs and outputs that contribute to theefficiency level.

\section{Variable of Operationalization}

This table would show input and output variable as operationalization variable to measure the efficiency level of DompetDhuafa Program from 2010-2013, as follow:

Tabel 1.Input - Output Variable

\begin{tabular}{|c|c|c|}
\hline Input Variable & Definition & Source \\
\hline Input $1\left(\mathrm{X}_{11}\right)$ & Operating Expenses & Financial Statement \\
\hline Input $2\left(\mathrm{X}_{21}\right)$ & Socialization Cost & Financial Statement \\
\hline Output Variable & Definition & Source \\
\hline Output $1\left(\mathrm{Y}_{11}\right)$ & Total Deposit Zakat & Financial Statement \\
\hline Output $2\left(\mathrm{Y}_{21}\right)$ & Total Fund Distribution & Financial Statement \\
\hline
\end{tabular}

Source: Rusydiana (2013)

\section{ANALYSIS AND DISCUSSION Efficiency Score ofDompetDhuafa Program}

In Table 1 below can be seen, DompetDhuafa program thatinclude toefficient (Constant 100\%) in 2013 areinfak fund and zakat program. While DompetDhuafa program that includetoefficient in 2011 was zakat program. Moreover, DompetDhuafa programs that include to efficient in 2010 are humanity fund, wakaf and certaininfak. Based on the explanation, the lowest efficiency of DompetDhuafa program is Wakaf fund in 2012. This is able to be a consideration for other program in DompetDhuafa that has not been efficient in order to improve the technical efficiency.

In addition, the DMU (DompetDhuafa programs) is inefficient divided into two parts, both Increasing Return to Scale (IRS) and Decreasing Return to Scale (DRS). In this case, DompetDhuafa program which still inefficient include to IRS, arecertain infak fund (2011), certain infak fund (2012), zakat (2012), wakaf fund (2011), zakat (2010), infak fund (2012), infak fund (2011), humanity fund (2011), infak fund (2010), THK (2013), certain infak fund (2013), humanity fund (2013), THK (2012), humanity fund (2012), wakaf fund (2013), THK (2010), THK (2011), and wakaf fund (2012). To achieve an efficient level of each program that include to inefficient, it can be cultivated with a view of its potential improvement. 
Table 2. Efficiency Score of DompetDhuafa Program

\begin{tabular}{|c|c|c|c|}
\hline No & Name & Score & Scale \\
\hline 1 & 2010Humanity Fund & 100 & Constant \\
\hline 2 & 2013Infak Fund & 100 & Constant \\
\hline 3 & 2010 Wakaf Fund & 100 & Constant \\
\hline 4 & 2010Certain Infak Fund & 100 & Constant \\
\hline 5 & 2011 Zakat & 100 & Constant \\
\hline 6 & 2013 Zakat & 100 & Constant \\
\hline 7 & 2011 Certain Infak Fund & 97.04 & Increasing \\
\hline 8 & 2012 Certain Infak Fund & 91.93 & Increasing \\
\hline 9 & 2012 Zakat & 91.00 & Increasing \\
\hline 10 & 2011 Wakaf Fund & 85.61 & Increasing \\
\hline 11 & 2010 Zakat & 82.16 & Increasing \\
\hline 12 & 2012 Infak Fund & 73.93 & Increasing \\
\hline 13 & 2011 Infak Fund & 68.11 & Increasing \\
\hline 14 & 2011Humanity Fund & 66.67 & Increasing \\
\hline 15 & 2010 Infak Fund & 59.11 & Increasing \\
\hline 16 & $2013 \mathrm{THK}$ & 58.24 & Increasing \\
\hline 17 & 2013 Certain Infak Fund & 55.42 & Increasing \\
\hline 18 & 2013 Humanity Fund & 49.80 & Increasing \\
\hline 19 & $2012 \mathrm{THK}$ & 49.76 & Increasing \\
\hline 20 & 2012 Humanity Fund & 43.05 & Increasing \\
\hline 21 & 2013 Wakaf Fund & 41.68 & Increasing \\
\hline 22 & $2010 \mathrm{THK}$ & 41.44 & Increasing \\
\hline 23 & $2011 \mathrm{THK}$ & 37.78 & Increasing \\
\hline 24 & 2012 Wakaf Fund & 19.50 & Increasing \\
\hline
\end{tabular}

Source: Own calculation

\section{Distribution of Efficiency Score}

Information based on the previous table, the graph below provides information about the number of business units (DMU) are efficient and inefficient on a scale of a particular group. Based on the following chart can know the number of efficient program (100\%), there are 6 programs that include to fully efficient. The graph below also provides information that most business units are in efficiency $100 \%$, namely 6 DMU, while the least DMU with the level of efficiency of $11 \%-20 \%, 31 \%-40 \%$, and $71 \%-80 \%$, every single level is 1 DMU. 


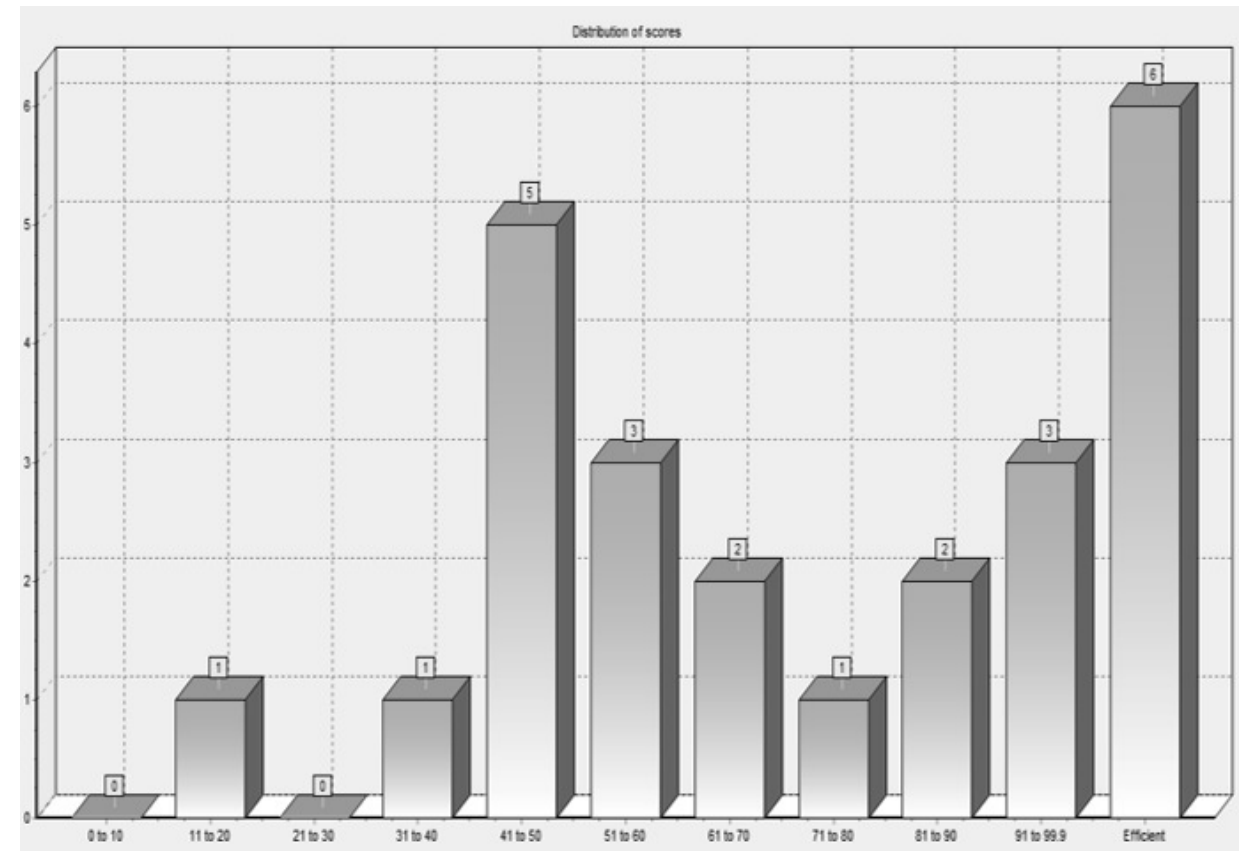

Figure 3. Distribution of Efficiency Score

Source: Own calculation

\section{Total Potential Improvement of Zakat Institution Program}

To find out the source of inefficiency from DompetDhuafa program in this study, it can be seen through the total potential improvement in the information below to provide a general overview associated with program that include to inefficient. Graph of total potential improvement mention that, in order to be efficient, inefficient program should reduce socialization cost until $2.66 \%$ and operating costs to $0.67 \%$. While for the revenue fund needs to be increased up to $21.29 \%$ and distribution fund to $75.38 \%$ in order to achieve optimal efficiency levels.

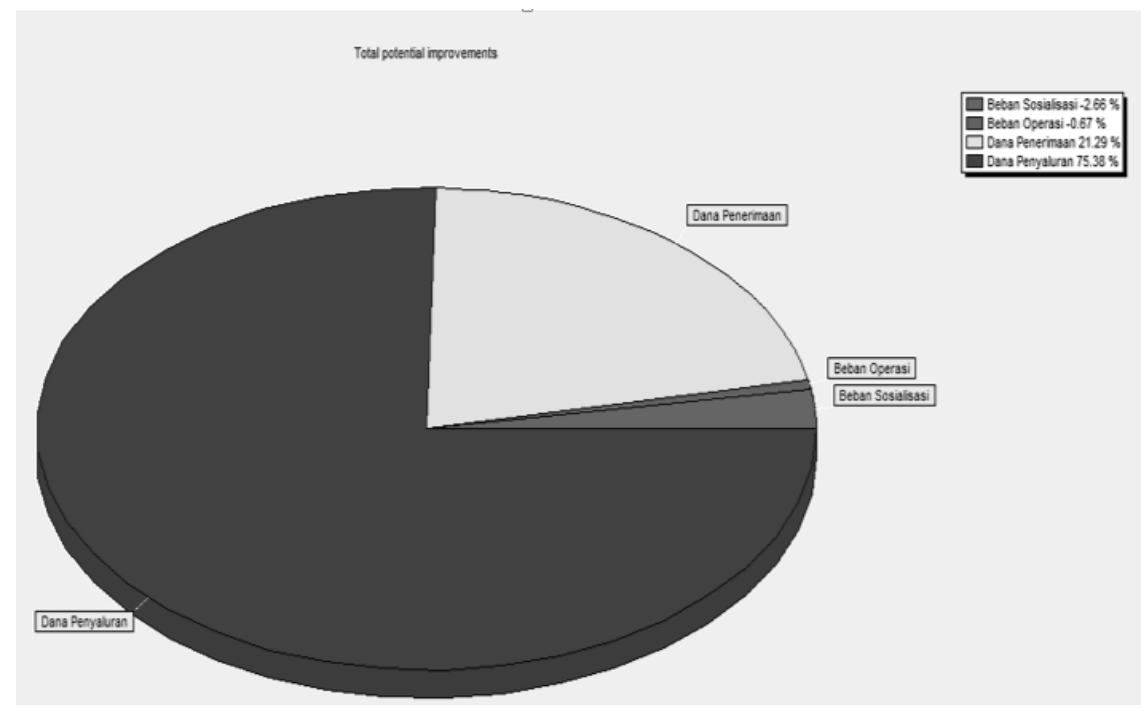

Figure 4. Total Potential Improvement

Source: Own calculation 


\section{Reference DMU}

Here, the authors would explain about program as the reference to other programthat still inefficient. From the calculation of frontier analysis shows that the most programreferenced in 2010 arewakaffund, referenced by 18 DMU, humanity fund referenced by 7 DMU, and certain infak fund referenced by 3 DMU. While in 2013, the most program referenced arezakat, referenced by 7 DMU and infak fund referenced by 6 DMU.

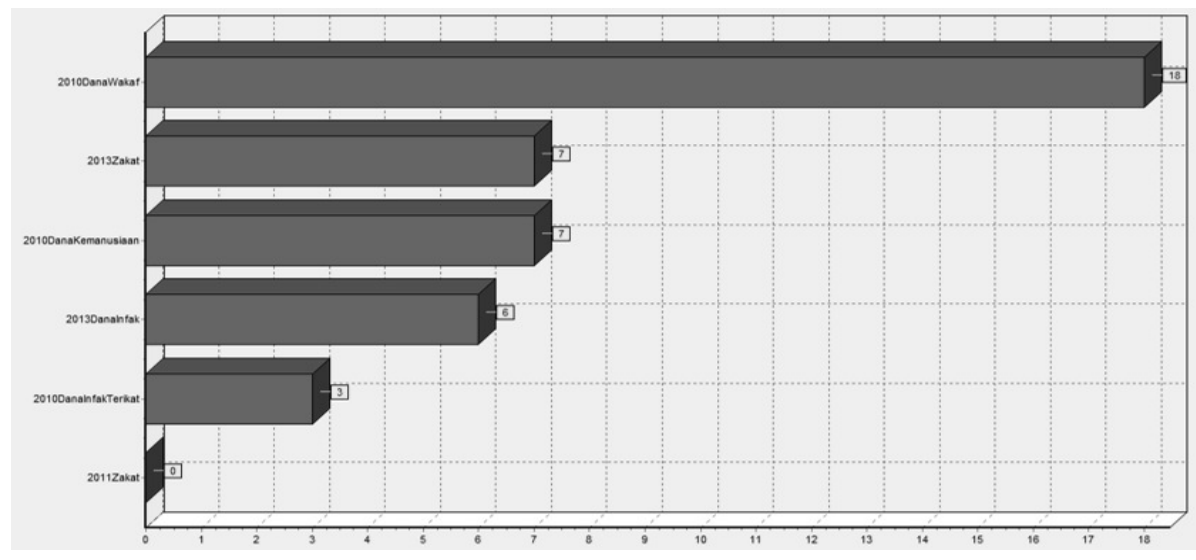

Figure 5. Reference Frequencies

Source: Own calculation

\section{Analysis of Inefficient DMU}

This section would describe the potential improvement from the lowest efficiency level of DompetDhuafa's program, namely wakaf fund (2012). According to the first unit detail graphics in below, explained that in order to achieve the level of efficiency, wakaf fund (2012) has to improve revenue fund up to $414 \%$ and the distribution fund up to $5232 \%$.

In the second chart,it explains about the reference comparison of wakaf fund (2012) shows that, to achieve a level of optimum efficiency, wakaf fund (2012) may be referring to two programs referenced, that arewakaf fund (2010) and infak fund (2013). For example, the comparison between wakaf fund (2012) andwakaf fund (2010), the use of operating cost of wakaf fund (2010) amounted to $162 \%$, and the use of socialization cost is $100 \%$, with distribution fund amounted to $9668 \%$ and revenue fund by $553 \%$.

Then, in the next graph about the chart of input/output contribution. The efficiency level of wakaf fund (2012) amounted to $19.5 \%$. According to the chart, variables that contribute to the efficiency of wakaf fund (2012) in achieving an efficiency levelas much as $19.5 \%$ are operational costs by $100 \%$ and revenue fund amounted to $100 \%$. This indicates that the operating costs and revenue fund have contributed to achieve the efficiency rate of wakaf fund (2012) amounted to $19.5 \%$.

Furthermore, the last chart about the reference contribution chart, it explains the contribution of each business unit was referred by wakaf fund program (2012). Based on the chart below, the nearest business unit (DMU) which can be referenced by wakaf fund program to four variables (input and output) are wakaf fund (2010), and then followed by infak fund (2013). 

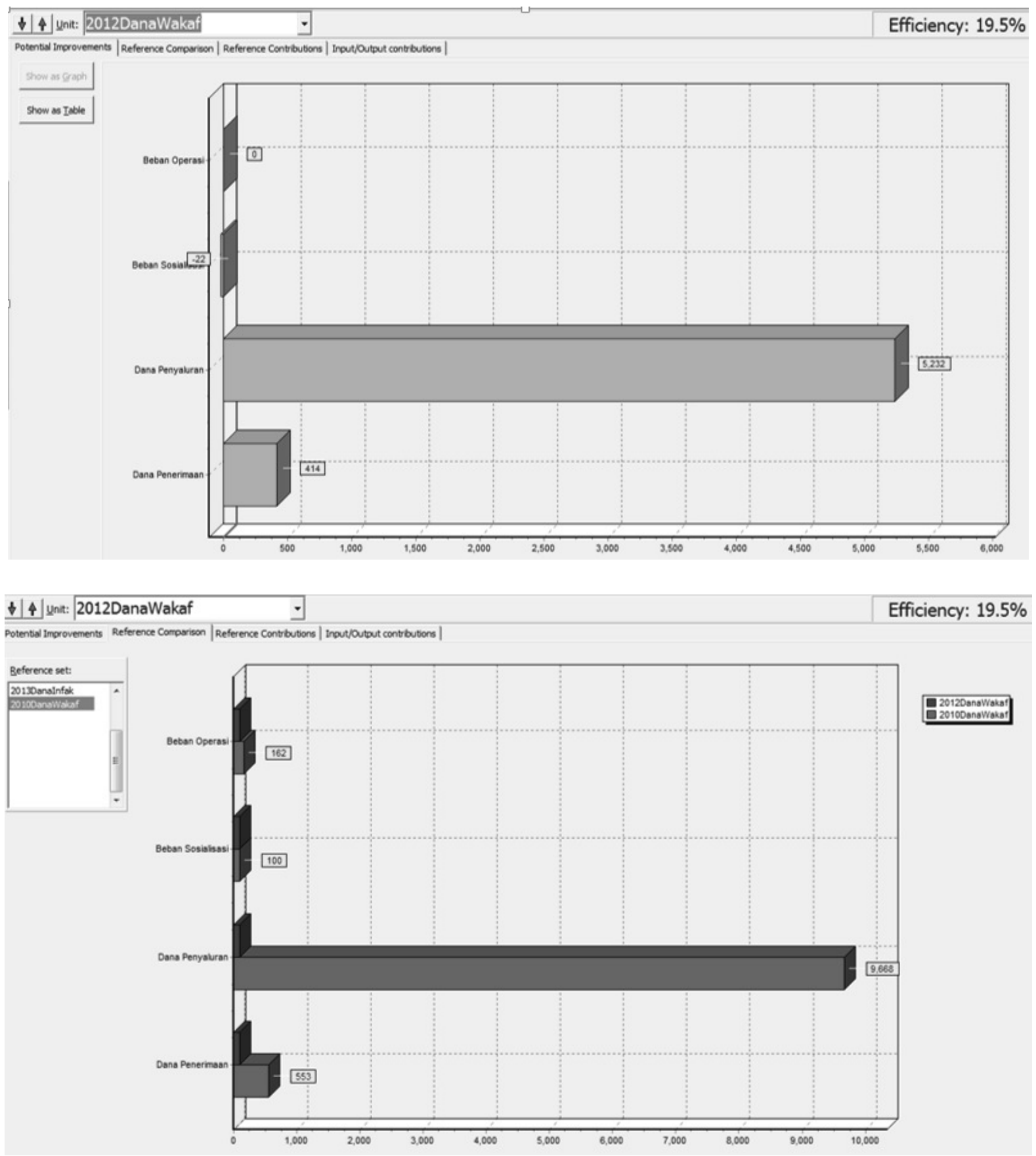

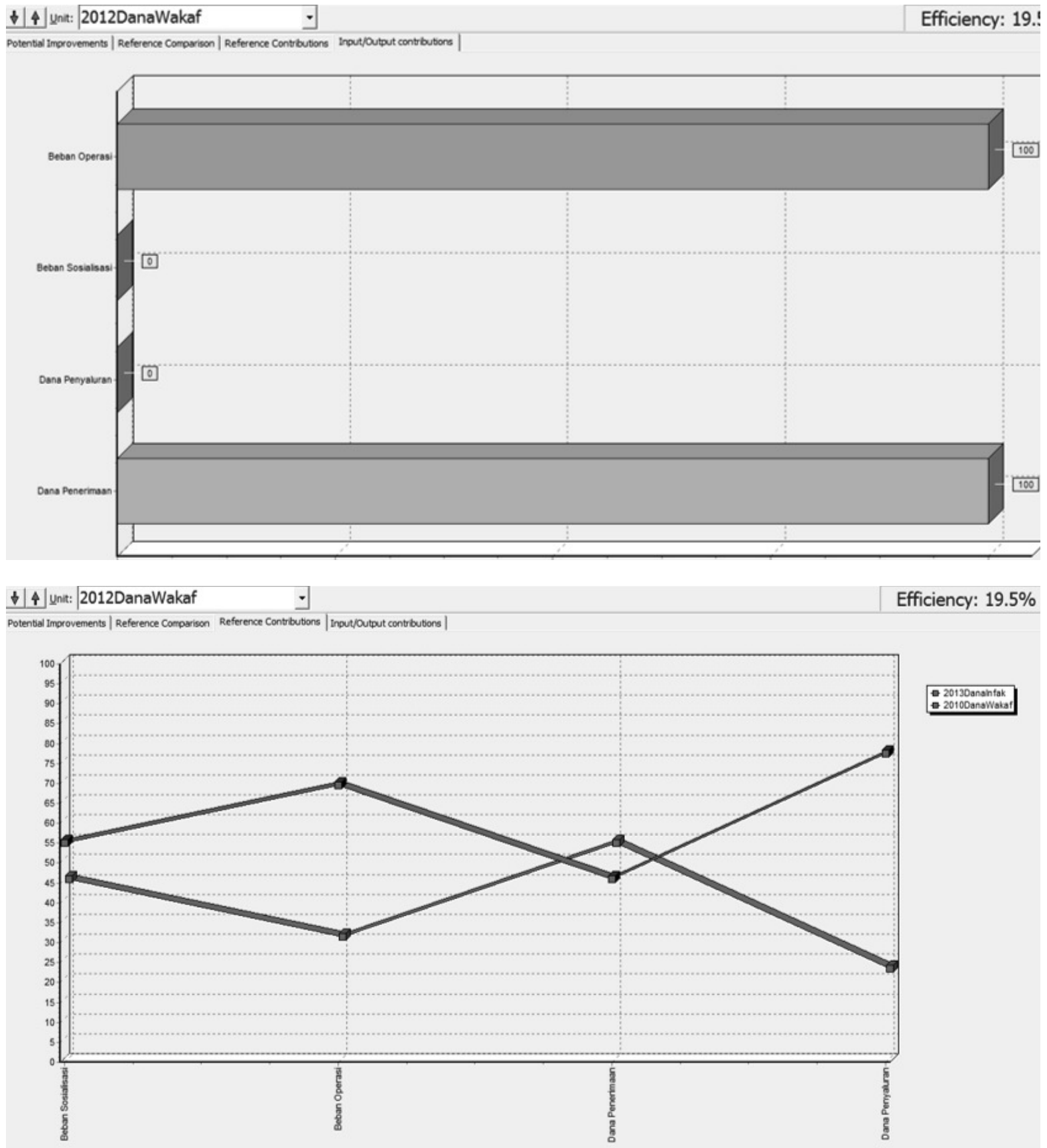

Figure 6. Unit Details: Wakaf Fund2012

Source: Own calculation

\section{CONCLUSION}

Research on efficiency of DompetDhuafa program is important to do. Here are some of the conclusions and recommendation:

\section{Conclusion:}

1. There are 6 DMU that efficient (100\%). And inefficient as much as 18 DMU. DompetDhuafa Program that include to relative efficient are humanity fund (2010), wakaf fund (2010), certain infak fund (2010), zakat (2011), infak fund (2013), zakat (2013). And the most inefficient program is wakaf fund (2012). 
2. Graph of total potential improvement mention that, in order to be efficient, inefficient program should reduce socialization cost until $2.66 \%$ and operating costs to $0.67 \%$. While for the revenue fund needs to be increased up to $21.29 \%$ and distribution fund to $75.38 \%$ in order to achieve optimal efficiency levels.

3. In general, the main inefficiency factor of DompetDhuafa program from 2010 to 2013 due to the distribution fund of DompetDhuafa program such as zakat, wakaf, humanity etc to who need it (ashnaf) which still less optimal. This is in line with the result, states that distribution fund has to increase up to $75.38 \%$, then it is able to resolve the problem of poverty.

4. DompetDhuafa program which still inefficient include to IRS, are certain infak fund (2011), certain infak fund (2012), zakat (2012), wakaf fund (2011), zakat (2010), infak fund (2012), infak fund (2011), humanity fund (2011), infak fund (2010), THK (2013), certain infak fund (2013), humanity fund (2013), THK (2012), humanity fund (2012), wakaf fund (2013), THK (2010), THK (2011), and wakaf fund (2012). In addition, the most program referenced in 2010 arewakaf fund, referenced by 18 DMU, humanity fund referenced by 7 DMU, and certain infak fund referenced by 3 DMU. While in 2013, the most program referenced are zakat, referenced by 7 DMU and infak fund referenced by 6 DMU.

\section{RECOMMENDATION:}

1. Financial statement data useful for researchers/academics to be used as a source of research data. The ultimate goal is improvement and development of zakat and OPZ in Indonesia.

2. Zakat Institutions, both public and private sector need to do the counting of efficiency levels routinely and regularly so that it knows the efficiencylevel, potential improvement and its benefit and weakness in general, within the framework of efficiency analysis.

3. Due to limited data that the authors obtained, the number of observations is small relatively, although it is still tolerated.For future research, the author is able to add the number of observation from all of OPZ in Indonesia. Therefore, the need for every Zakat Institution (OPZ) both public and private to issue annual financial statements in order to increase accountability and transparency in the management of funds.

\section{REFERENCES}

Akbar, N. (2009). Analisis Efisiensi Organisasi Pengelola Zakat Nasional Dengan Pendekatan Data Envelopment Analysis. Tazkia Islamic Finance and Business Review, 4(2), 760784.

Ahmad, I. H. J., \& Masturah, M. (2014). The Efficiency of Zakat Collection and Distribution: Evidence from Two Stage Analysis. Journal of Economic Cooperation and Development, 35(3), 133-170.

Banker, R. D., Charnes, A., \& Cooper, W. W. (1984). Some Models for Estimating Technical and Scale Inefficiency in Data Envelopment Analysis. Management Science, 30(9), 1078-92. 
Berber, P., Brockett, P. L., Cooper, W. W., Golden, L. L., \& Parker, B. R. (2011). Efficiency in Fundraising and Distributions to Cause-related Social Profit Enterprises. SocioEconomic Planning Sciences, 45, 1-9.

Bauer, P.W., Berger, A. N., Ferrier, G. D., \& Humphrey, D. B. (1998). Consistency Conditions for Regulatory Analysis of Financial Institutions: A Comparison of Frontier Efficiency Methods. Financial ServicesWorking Paper, 2(97), 1-30 Federal Reserve.

Beik, I.S,Nursechafia, Muljawan, D. Yumanita, D. Fiona, A \&Nazar, J.K.(2014). Towardss an Establishment of an Efficient and Sound Zakat System: Proposed Core Principles for Effective Zakat Supervision. Paper presented in the Working Group of Zakat Core Principles 2014.

Charnes, A, Cooper, W.W, \& Rhodes, E. (1978). Measuring the Efficiency of Decision Making Units.European Journal of Operation Research, 2(6), 429-44.

Cooper, et al. (2002). Data Envelopment Analysis. Kluwer Academic Publisher, USA.

DD.(2016).Financial Statement of Dompet Dhuafa Year 2010-2013.

Farrel, M.L. (1957). The Measurement of Productive Efficiency.Journal of The Royal Statistical Society, 120 (3) , 253-281.

Hussain, A \& Jones, M. (2010). An Introduction to Frontier Analyst Version 4.0. Banxia Software Ltd.

Jemric, I \& Vujcic, B. (2002). Efficiency of Banks in Croatia: A DEA Approach. Croatian National Bank, Working Paper 7.

Kamarudin, B.H, Safa, M.S \&Mohd.R.(2008). Assessing Production Efficiency of Islamic Banks and Conventional Bank Islamic Windows in Malaysia. International Journal of Business and Management Research, 1(1), 31-48.

Kumbhaker, S.C. \& Lovell.(2000). The Measurement of Technical Efficiency.Journal of The Royal Statistical Society.

Noor, A.H.M,Rasool, M.S.A, Rahman, R.A, Yusof, R.M, \& Ali, S.M.(2012). Assessing Performance of Nonprofit Organization: A Framework for Zakat Institutions. British Journal of Economics, Finance and Management Sciences, 5(1).

Noor, A.H.M, Rasool, M.S.A, Rahman, R.A, Yusof, R.M, \& Ali, S.M. (2015). Efficiency of Islamic Institutions: Empirical Evidence of Zakat Organizations Performance in Malaysia. Journal of Economics, Business and Management,3(2).

Norazlina A.W \&Abdul R.A.R. (2011). A Framework to Analyze the Efficiency and Governance of Zakat Institutions. Journal of Islamic Accounting and Business Research, 2(1), 4362.

Norazlina A.W.\&Abdul R.A.R. (2012). Efficiency of Zakat Institutions in Malaysia: An Application of Data Envelopment Analysis.Journal of Economic Cooperation and Development, 33(1), 95-112. 
Nur, H.I \& Selamah, M. (2013). Kajian Kecekapan Kutipan Zakat di Wilayah Persekutuan. Prosiding PERKEM VIII, 1, 414 - 425.

Ozdemir, A. (2013). Integrating analytic network process and data envelopment analysis for efficiency measurement of Turkish commercial banks. Banks and Bank Systems, 8(2).

Rusydiana, A,S, Maliha, H\&Parisi, S.A. (2016). Data Envelopment AnalysisuntukPengukuran Tingkat Efisiensi OPZ. Paper accepted at The $4^{\text {th }}$ South East Asia International Islamic Philanthropy Conference, held at Bandung Indonesia 25-27 th February 2016.

Rusydiana, A.S.\& Tim SMART Consulting. (2013). Mengukur Tingkat Efisiensi dengan Data Envelopment Analysis.Bogor: SMART Publishing.

Shahreki, J, Nazar D \& Ghasemi, M.A. (2012). Efficiency Evaluation Bank Sepah Branches in Sistan and Baluchestan Province Using Data Envelopment Analysis. Interdisciplinary Journal of Contemporary Research in Business, 4(2).

Tanjung, H and Devi, A. (2013). Metodologi Penelitian Ekonomi Islam. Bekasi: Gramata Publishing.

Tsolas, I.E. \& Dimitris I.G. (2012). Bank branch efficiency evaluation by means of least absolute deviations and DEA. Managerial Finance, 38(8).

Wahab, N.A\&Rahman, A.R.A. (2012). Efficiency of Zakat Institutions in Malaysia: An Application of Data Envelopment Analysis. Journal of Economic Cooperation and Development, 33(1), 95-112.

Wahab, N.A. \&RahmanA.R.A. (2013). Determinants of Efficiency of Zakat Institutions in Malaysia: A Non-parametric Approach. AsianJournal of Business and Accounting, 6(2). 